\title{
Consumer Perception about Selected Aspects of Global and Local Brands
}

\author{
Dr. Trilok Pratap Singh ${ }^{a}$ \\ ${ }^{a}$ Assistant Professor, Institute of Business Management, GLA University, Mathura-Delhi Road, Chaumuhan, \\ Mathura (U.P), India. E-mail: trilok.pratap@gla.ac
}

Article History: Received: 11 January 2021; Accepted: 27 February 2021; Published online: 5 April 2021

\begin{abstract}
The aim of this paper is to examine the relationship between consumer brand equity (CBE). This work examines the gaps between global and local brands in the Indian market. Attitudes towards items around the world and the casual clothing brand of the Indian market are being investigated. Brand equity, consisting of brand identity, impact on the perception of consumer products regardless of age (people, inclination to local brands, personal experience, costs, advertising, sponsorships and endorsements) are recognized. A total of 255 students took part in the survey. This research shows that Indian consumers perceive global and local brands differently based on brand meaning.
\end{abstract}

Keywords: Global and Local Brands, Brand commitment, Consumer Brand Equity, Brand Identity, Attitudes, Consumer Perception, Advertising, Sponsorships, Endorsements.

\section{Introduction}

Consumers are increasingly confronted with differences between global and local brands, making it worthwhile to study their consumer choice (Bharadwaj, 2005). Unlike the success of other large corporations, globalization can also give local firms competitive advantages through deep understanding and proximity to consumers (Ger, 1999). Consumers are more likely to choose global brands because they can add reputation, profits and prestige to and further enhance consumer self-identity (Alden et al., 1999). However, in situations, customers prefer international brands to local brands. Brands generally known as global brands are widely available throughout the world (Dimofte et al., 2008). Global research of the brand Addidas to Zara has repeatedly shown its advantages over other brands. This has more positive effects on multinational brands (Alden et al., 1999). Associating multinational brands with a desire to live in more developed economies (Alden et al., 1999) and global consumers combine high quality consumer goods with a common philosophy of social responsibility (Holt et al., 2004).

Because of a variety of reasons, such as lowering close demands, increasing resistance to local markets, drastic limits, etc., and more companies are looking for new markets and save their own (Clark and Goldsmith, 2005). Several companies have created and are developing brands from around the world to boost the competitive edge of their competitors. International brands in most countries where a company exists are companies with similar locations, promotional strategy, logo, image and popularity (Aaker and Joachimsthaler, 1999). However, under certain market conditions, companies may adapt their products to a degree that does not fully reflect the characteristics of the products (Apaydin and Koksal, 2009). A major issue with branding, the notion of value added, is a consistent perception of price (Cummins and Gullone, 2000). Others are economies of scale, with major impacts on sales amortization, marketing, R\&D and operating costs due to increased competition due to global presence. Companies selling global goods (whether distributors, manufacturers or brand names) have become increasingly important within the organization to benefit from the use of economies of scale, global production and distribution networks (Kimet al.,2002). The potential number of consumers is that of increasing market penetration. Companies then put in place strategies to expand their consumer portfolio and bring global brands to new markets. Second, domestic brands give advertisers a strategic advantage as producers gain customer advantages and a superior supply chain over global brands (Gerefi, 2001).

Companies have developed global networks through globalization, giving supply chains a strategic advantage over local companies. Another explanation for emerging global brands is the trade links between developing countries. After the 1960s, the global economy mainly consisted of cross-border movements of money, commodities and people (Kinra et al., 2006). Economic growth has ensured that exchange rates are falling, enabling businesses to market their goods globally. Higher investment in trade increases retail leverage, freeing up more direct marketing funds (Lau and Phau, 2007). Eventually, the recognition of global brands (reflecting identity brands) and reputation (collective representation of brand representations from different electoral districts) help marketers create productive partnerships that involve considering the role of global brands in risk management in specific cultural markets (Argenti and Druckenmiller, 2004).

Therefore, in order to prevent the touch, perception and awareness of market-related factors such as brand identity. When trade advances are made, export costs are declining, allowing businesses to sell their products abroad. Essentially, when purchasing, customers attribute certain attributes to global brands and use them as requirements (Alden et al., 2006). In line with this, it's unbelievable to understand the interest of shoppers in an unmistakable country before marketers hit another area. Advertisers are looking professionally at the problem of 
how consumers view global brands. Several comments on customer knowledge have been made over the last few years. In the light of these results, developers have accepted that data from managers and analysts is a great source, in one sense. Because of a variety of reasons, such as lowering close demands, increasing resistance to local markets, drastic limits, etc., and more companies are looking for new markets. Several companies have created and are developing brands from around the world to boost the competitive edge of their competitors (Piacentini and Mailer, 2004). International brands in most countries where a company exists are companies with similar locations, promotional strategy, logo, image and popularity (Aaker and Joachimsthaler, 1999). However, under certain market conditions, companies may adapt their products to a degree that does not fully reflect the characteristics of the products (Apaydın and Koksal, 2009).

A major issue with branding, the notion of value added, is a consistent perception of pricem (Escalas and Bettman, 2005). Others are economies of scale, with major impacts on sales amortization, marketing, R\&D and operating costs due to increased competition due to global presence. Companies selling global goods (whether distributors, manufacturers or brand names) have become increasingly important within the organization to benefit from the use of economies of scale, global production and distribution networks (Grixti et al.,2006).The potential number of consumers is that of increasing market penetration. Companies then put in place strategies to expand their consumer portfolio and bring global brands to new markets. Second, domestic brands give advertisers a strategic advantage as producers gain customer advantages and a superior supply chain over global brands (Hollenbeck and Zinkhan, 2006). Companies have developed global networks through globalization, giving supply chains a strategic advantage over local companies. Another explanation for emerging global brands is the trade links between developing countries. After the 1960s, the global economy mainly consisted of cross-border movements of money, commodities and people (Yeung, 1997). Economic growth has ensured that exchange rates are falling, enabling businesses to market their goods globally. Higher investment in trade increases retail leverage, freeing up more direct marketing funds. Eventually, the recognition of global brands (reflecting identity brands) and reputation (collective representation of brand representations from different electoral districts) help marketers create productive partnerships (Jenks et al., 2003).

Therefore, in order to prevent the touch, perception and awareness of market-related factors such as brand identity. When trade advances are made, export costs are declining, allowing businesses to sell their products abroad. Essentially, when purchasing, customers attribute certain attributes to global brands and use them as requirements (Maclaran and Brown, 2005). In line with this, it's unbelievable to understand the interest of shoppers in an unmistakable country before marketers hit another area (Kang and Herr, 2006). Advertisers are looking professionally at the problem of how consumers view global brands. Several comments on customer knowledge have been made over the last few years. In the light of these results, developers have accepted that data from managers and analysts is a great source, in one sense. Customer service consists of five separate tasks, as shown in the figure. The key objective is to improve the presentation. The second one shows a need for boosts. In the third wave of Partnership, people are writing jolts that need to be felt and carried. The fourth step is post-consciousness. Mid-final service is going to keep records.

\section{Literature Review}

"Branding is inextricably linked to the core marketing principles," says Arnold. "Marketing is about understanding two forms of demand: needs that define boundaries and critical factors for consumer success; and wants" extras "that consumers love and use to differentiate between alternative products (Speck and Roy, 2008). Brand awareness involves customer awareness, brand recognition. It may be brand awareness and brand awareness. There is no brand interest without brand recognition (Sandikci and Omeraki, 2007). Brand marketing continues to dominate the world, as studies have shown a clear correlation between superior quality, global consumer awareness and higher social status (Alden et al., 2013). Zhang (2009), are talking about the globalization of the global market based on national brands. There is proof everywhere: in cities, in stores and in the media. Brands around the globe use their strengths and results differently. Buyers are financially pursuing the high-value premiums on these labels

Worldwide brands embody consumer identity, sense of achievement and evidence, reflecting the goaloriented aspirations of the buyer community around the world. Global brands are available globally and are well known according to Deari and Balla, 2013). The word "big brand" applies to firms selling at least $20 \%$ of goods outside their countries or regions (Townsend et al., 2009). They also found (44 per cent) of respondents from 16 global brands that the price was the key reason for choosing a global brand, business theory and social responsibility was 12 per cent, followed by 8 per cent. In other words, one name and/or logo is used by multinational companies. In a study by Balabanis and Diamantopoulos (2011), global brands are said to have more interest because of their reputation and popularity than local brands, all of which are equal. Global brands tend to be considered larger and better than national or local brands (Dimofte et al., 2008). Consumers view global brands as icons of shared ideals from a cultural point of view (Atilgan et al., 2009) others around the world. Many of these brands have achieved worldwide recognition icons, their own symbolic forms (Baalbaki and Guzm, 2016). 
Chatzipanagiotou et al., (2016) continues to argue that core principles and recognizable label features are more likely to remain consistent across countries than peripheral labels. The peripheries of the company are increasingly restrained and adapted to the contrast between homes (Eelen et al., 2017). Center products are often institutionalized, while the benefits of the brand are also modified by enabling components to be combined. Consumers across nations can differentiate and recognize brands around the world. Too, brands around the world are renowned for their qualities. Hayes (2013), point out that the following features refer to global brands: Geographical scope: available in both large and small markets. Globally perceived customers: Customers realize that the brand is sold worldwide (Kumar, 2009). Brand and uniform positioning: Peter England, Adidas, H\&M, Zara, etc. Loyalty determines the consumer's loyalty to a particular supplier, as opposed to rivals, but is not a reliable predictor of buying behaviour. Engine participation is a key component of purchasing behavior. Keller (2019), divided client loyalty into loyalty programming.

The public appeal is also directed at non-specific ethnic dressing tendencies. Consequently, the new mold dress commercial, which focuses on the implementation of ethnic dressing, is at the heart of a traditional community whose exquisite fabrics have been designed for lodging. This is an opportunity to incorporate improvements in form and consumer culture in order to build creativity that will fuel the clothing offering (Maaninou et al., 2019). The three-dimensional digital made-to - measure plot, displayed in large department stores and based on PC leisure lifestyle, plays an important role in fashion clothing excitement. Clothing fashion designers, designers and retailers are welcome to explore creative geometric clothing models through freestyle design (Parket al., 2016). Clothing objects are specifically designed for the components of the human body, and the components that share the traditional human configuration are along those lines. This parametric view helps to contrast the body shapes of the programmed era of personalized clothing objects. Customers lean to buy these clothes, sold primarily as molded clothing (Ortiz et al., 2013).

Perception is essentially a life-form reflecting a clear image of a human being that some entity or administration anticipates. Recognition can be defined as "Why we see our general environment." Customers are individuals, and they see it differently in certain situations (Rajasekar and Nalina, 2008). The interpretation of the item is more relevant than the item itself, and the companies provide opinions on the item. When consumers have more options than they can count on, and each company makes a respectable attempt to advertise its own specialty, it is only the enchanting concept of a "name" that puts an end to the numerous "me" and rivals of each company (Torres et al., 2012). Then the brand is known as one of the most important products on the consumer market. The greater the continuity of brand identity and customer image, the greater the market view of the brand and the greater their desire to purchase it (Van et al.,2018). Customer understanding is increased by increasing scale and decreased by higher sacrificial levels. For example, the quality of extrinsic measures such as brand name and price may influence consumer quality decisions (Veloutsou et al., 2013).

Products have been continuously checked and redefined in the marketing literature, and the meaning of 'name' varies. Another classic concept put forward by the American Marketing Association (2011) is: names, words, styles, symbols or any other attribute that distinguishes the products or services of one seller from those of other sellers. Label is the legal word for labels. One object, a family of things, or any of the items identified by the name of the seller. The chosen word is the trade name if it is used as a whole. Marques compete in different categories. This study compares the local brand to the global brand. If the customer assumes that the brand is sold in many countries and known internationally, the brand will be considered internationally. A global brand is readily available to men in many countries (Staudt et al., 2014). Multinational brands have a strong global reputation. For any field that's usually just as true. The global brand is tailoring its message to a variety of languages and cultures. The basic requirements of the Global Brand are the Nike, Procter \& Gamble, IBM, LVMH, Lenovo and Singapore airlines (Romaniuk et al., 2018).

Regional brands are known as national brands. Local products are often available on the neighborhood market, linking and symbolizing the local nation and culture (Zarantonello et al., 2016). When it comes to shopping, it is possible to select a local brand to distinguish variables such as: individuals in a particular community, for example, neighborhood rituals and events, neighborhood culture uniqueness, etc. Consumers may receive a trademark attached to the local community on the basis of an ebb and flow validation order (Li et al., 2017).

Steenkamp, (2003) conducted a survey of consumer expectations for local products. We found consumers 'preference for a global brand dictated by Brand Globalness' perceived consistency, greater reputation, and perceived psychological benefits. These three dimensions describe the component that affects consumer purchasing decisions. Brand recognition is one of the key elements of branding and is defined as the ability of a potential customer to identify or recall that branding is part of a specific product category (Wadhwa et al., 2015). Increased brand awareness is triggered by repeated exposure, positive comparisons and signal use (Samiee, 2019). Brand awareness can be defined as information about the brand stored in the memory of the customer (Pittaand Franzak, 2008). 
Brand recognition is the intensity of the brand and can be seen in the identification of the brand under different conditions. It's a combination of thanks and reminders. Keller (1993) notes that brand recognition is an essential prerequisite for the growth of brand identity. Brand loyalty (Jacoby and Chestnut 1978) has played a key role and can also be described as a bias (non-random) behavioral reaction (repurchase, referral, price sensitivity) that has been articulated over time by some brand decision-makers and is based on psychological processes for one or more brands (Zhang et al.,2014). Many consultants and analysts say that three of them should have a "solid approach" to the commitment of a true brand. A local brand may be known as a brand within a country or area. The Global Brand can be described as "a brand marketed under the same name with similar, centrally located, coordinated marketing strategies in multiple countries" (Schuiling et al., 2004). This study shows that high retail stocks favor local brands, enjoy more market recognition than foreign brands, and have a strong brand identity. Local brands tend to have lower prices than foreign brands, giving customers more value for money.

Winit et al.,2014)) found that international brands with three key features of Price Signal, Business Theory and Social Responsibility are globally combined and assessed by consumers. Consumers prefer international brands that are generally of higher quality and promise than others. Consumers often see global products as goods which, when consumed, transmit international citizenship (Zarantonello and Pauwels, 2015). Typical Indian considers large brands to be luxury products. Consumers prefer to judge global brands on higher product and service quality (Zarantonello et al., 2013).

The drawbacks of mentally variable postures are that at least two individuals with identical stimuli would have fluctuating logics to meet the needs, expectations and desires of a person at home (Vukasovi et al., 2016). Likewise people may have the same social introductions, but they may feel different jolts. Several studies have identified the role of perceived performance, price perception, pre-purchase, perceived usefulness, positioning and advertising in influencing consumer purchasing behavior. This can be due to the degree of devotion to basic human ideals, expectations and self-conceptions (Oh and Kim, 2017). The variable often indicates "the amount of anticipation, urge or drive evoked by a specific stimulus or circumstance" Randrianasolo, (2017). The sociocultural dimension is made up of two difficult words to distinguish (Pichler and Hemetsberger, 2008). Social and cultural factors influence consumer purchasing behavior, including culture, religion, language, social background, family, geography (age, sex, work, occupation, employment, marital status) (Lieven and Hildebrand, 2016).

Friends and family come under a comparative package that includes gatherings or individuals whose excellent abilities, learning and personality make it possible for people to turn up and seek guidance. These are important sources of purchase power for goods. If a person has poor experience with one thing, he or she is more likely to stop having it. Social class and definitions are used to describe the social status of individuals or families. Training helps individuals develop awareness, skills and values of clothing choice while excluding other items (Ozsomer, 2012).

Access to desirable resources (money, services and merchandising) or personal satisfaction, such as reputation or recognition, is described by occupation. Weber concluded that the social class is characterized by distinct income, political power and individual status and that it is assumed that it has different attitudes towards certain food consumption. Jobs are the primary driver of customer revenue. Consumer orientation (ethnicity) is characterized as the consumer's interest in adequate, even decent, foreign goods. Ethnocentrism refers to the view of people, where their community is seen as the nucleus of the universe. Certification of success and profitbased strategies may be defined as social, public and financial benefits (Krautz, 2017).Comparative costs are also very clear in retail markets, with occasional secret discounts for consumers (though for large-scale shopping), which can encourage retailer cooperation through retail platforms (because it's easy to detect fraudulent agreements). On the other hand, this is relatively simple compared to other dimensions of market competition, as customer resales are practically impossible. Quality is defined as "subjective conceptions of things to come" (Kim and Heere, 2012). The hypothesis of expectation is a type of consumer-designed hypothesis confirmed or rejected by their perception of production after purchase and use. Subscriptions are often used in advertisements to enhance communication quality. With the amount of global sporting events advertisers are more likely to spend millions of dollars hiring popular athletes to boost their advertising strategies to align their product photos with those athletes' supporters (Katsikeas et al., 2016).

\subsection{Research Gap \& Scope for this Study}

Keller (2003), Lockshin et al., 2012) reported knowledge of the brand in their reports. Brand recognition, preference (or disavowal), brand loyalty and trial conditions are important (Heinberg et al., 2018). Composing a name blends familiarity with alertness. It is calculated using methods (assisted) and mark recognition / rating (Keller, 2003).

In this report, the researcher attempted to explore these sources. Several surveys were conducted to determine the market value of multinational products, not local ones. It is also intended to determine trends in consumer transactions. Customer tests goods using information that is both inherent and extrinsic to them. A lot of factors 
have an impact on the ability of consumers to purchase. The results show that the prices and quality of the service concerned are the most important factors affecting the final decision of the consumer.

In view of the fact that buyers usually compare brand prices with quality, too low market prices are generally referred to as low-quality commodities. Nor can a product that is too big cost anyone. Consumer tastes are influenced by: consumer ethnocentrism, country of origin, place within society, competition with competing brands, family and friends (Davvetas and Diamantopoulos, 2016). Here researchers compare the Global with local brands.

The factors which they were designed in their research are like purchase decision, quality and all. But they didn't consider the demographic factors which we have tried to add in this report. To sum up, the researcher is in a position to state that this research is only confined to examining the various sources of brand awareness, level of awareness of customers about several aspects of brands, measuring their perception regarding the global as well as local brand, and the factors affecting the level of awareness regarding these selected salient aspects of brand.

\subsection{Objectives of the Research}

A) Understanding global and local brand interactions.

- Identification of the label selected

- Factors affecting vulnerability

B) Customer awareness of the components of global and local brands.

C) Factors affecting the consumer understands of the product.

\section{Research Methodology}

Logical and systematic is the search for new, useful knowledge on a particular subject. Methodology is a systematic, theoretical study of the method used in science or a theoretical analysis of the collection of methods and principles related to information. Typical concepts shall include paradigms, models, phases and techniques of a quantitative or qualitative nature. The investigative method used is descriptive research describing the behavior of the subject.

\section{Hypothesis}

\begin{tabular}{|l|l|}
\hline \multicolumn{2}{|l}{ Hypothesis On The Basis Of Age } \\
\hline S.No. & \\
\hline Ho1: & $\begin{array}{l}\text { There is no significant difference among the various age groups of respondents as far as } \\
\text { the influence of the reference groups (family and friends) on their perception about the } \\
\text { brands is concerned. }\end{array}$ \\
\hline Ho2: & $\begin{array}{l}\text { There is no significant difference among the various age groups of respondents as far as } \\
\text { the influence of their inclination towards local products on their perception about the } \\
\text { brands is concerned. }\end{array}$ \\
\hline Ho3: & $\begin{array}{l}\text { There is no significant difference among the various age groups of respondents as far as } \\
\text { the influence of their personal experience on their perception about the brands is } \\
\text { concerned. }\end{array}$ \\
\hline Ho4: & $\begin{array}{l}\text { There is no significant difference among the various age groups of respondents as far as } \\
\text { the influence of comparative prices of various brands on their perception about the } \\
\text { brands is concerned. }\end{array}$ \\
\hline Ho5: & $\begin{array}{l}\text { There is no significant difference among the various age groups of respondents as far as } \\
\text { the influence of advertisements/sponsorships/endorsements on their perception about the } \\
\text { brands is concerned. }\end{array}$ \\
\hline
\end{tabular}




\begin{tabular}{|c|c|}
\hline \multicolumn{2}{|r|}{ Hypothesis On The Basis Of Income: } \\
\hline S. No. & Hypothesis \\
\hline Ho1: & $\begin{array}{l}\text { There is no significant difference among the various income groups of respondents as } \\
\text { far as the influence of the reference groups (family and friends) on their perception } \\
\text { about the brands is concerned. }\end{array}$ \\
\hline $\mathrm{H}_{02}:$ & $\begin{array}{l}\text { There is no significant difference among the various income groups of respondents as } \\
\text { far as the influence of their inclination towards local products on their perception about } \\
\text { the brands is concerned. }\end{array}$ \\
\hline $\mathrm{H}_{0} 3:$ & $\begin{array}{l}\text { There is no significant difference among the various income groups of respondents as } \\
\text { far as the influence of their personal experience on their perception about the brands is } \\
\text { concerned. }\end{array}$ \\
\hline Hot: & $\begin{array}{l}\text { There is no significant difference among the various income groups of respondents as } \\
\text { far as the influence of comparative prices of various brands on their perception about } \\
\text { the brands is concerned. }\end{array}$ \\
\hline Hos: & $\begin{array}{l}\text { There is no significant difference among the various income groups of respondents as } \\
\text { far as the influence of advertisements/sponsorships/endorsements on their perception } \\
\text { about the brands is concerned. }\end{array}$ \\
\hline
\end{tabular}

\subsection{Research Design \& Instrument Development}

A research design is a study framework or technique that serves as a guide to the collection and analysis of data. One of the most widely used tools for primary data assessment is the marketing study questionnaire. For this study, a formal, closed questionnaire was developed for the understanding of the consumer brand. Many of the questions were based on a similar scale of five points. This questionnaire began by asking the respondents about their various sources of awareness, their level of awareness about selected aspects of their preferred brand, and their level of perception about the brands of their choice on selected brands' aspects. Moreover, they were also asked to rate their opinion about the various factors affecting their level of perception about brands.

\subsection{Sampling, Data Collection \& Analysis}

The information for this study has been collected directly through the questionnaire. This study is based on primary data. The size of population was not clear earlier as this study was based on brand which is generally acceptable in every society. In this study the questionnaire was filled through online and offline means.255 questions were identified using non-probability sampling. In the related research, sufficient sample size was derived from a previous study of 120 to more than 500 samples. The good sign of online questionnaire is each one is filled up properly. i.e. 100\% responses came. Respondents were requested to fill the questionnaire appropriately with their own. Analyzed data collected in SPSS 20.0. A number of concise statistics (percentage, mean and standard deviation) and One Way ANOVA were collected for useful information.

\section{Data Analysis \& Interpretation}

Primary data is obtained from social networking sites using a formal questionnaire. Likert compiles 5-point responses Schniederjans, et al., 2006; (Khamalah and Lingaraj, 2003). Next, the variance measurement (ONE WAY ANOVA) measured these reactions. Compare the results for the third goal achieved.The self-governing questionnaire was the instrument used in this study, consisting primarily of five Likert point scales. The questionnaire consists of three main variables included in the theoretical model, such as brand knowledge, customer perception and consumer (global and local) perception factors. ONE-WAY ANOVA has brought 10 hypotheses to the test.

\subsection{Profile Analysis}

Table 4.1 shows that 57.3 per cent of respondents were male, while the remaining 42.7 per cent were female out of 255 . 
Table 4.1: Gender Classification of Respondents

\begin{tabular}{|c|c|c|c|c|c|}
\hline \multicolumn{6}{|c|}{ Gender } \\
\hline & & Frequency & Percent & Valid Percent & $\begin{array}{c}\text { Cumulative } \\
\text { Percent } \\
\end{array}$ \\
\hline \multirow{3}{*}{ Valid } & Male & 146 & 57.3 & 57.3 & 57.3 \\
\hline & Female & 109 & 42.7 & 42.7 & 100.0 \\
\hline & Total & 255 & 100.0 & 100.0 & \\
\hline
\end{tabular}

Table 4.2 shows that $7.5 \%$ of respondents in the general population are under the age of $20,85.9 \%$ of respondents are over the age of 20, but less than $5.9 \%$ of respondents are over the age of 30 and over the age of 40 , while the remaining 8 are over the age of 40 .

Table 4.2: Age group differentiation

\begin{tabular}{|c|c|c|c|c|c|}
\hline \multicolumn{6}{|c|}{ Age } \\
\hline & & Frequency & Percent & Valid Percent & $\begin{array}{c}\text { Cumulative } \\
\text { Percent }\end{array}$ \\
\hline \multirow{5}{*}{ Valid } & Below20 & 19 & 7.5 & 7.5 & 7.5 \\
\hline & $20-30$ & 219 & 85.9 & 85.9 & 93.3 \\
\hline & $30-40$ & 15 & 5.9 & 5.9 & 99.2 \\
\hline & 40 and Above & 2 & .8 & .8 & 100.0 \\
\hline & Total & 255 & 100.0 & 100.0 & \\
\hline
\end{tabular}

From the Table 4.3, it shows that $7.5 \%$ of respondents are having qualification of below graduation, $32.2 \%$ of respondents are having qualification of graduation and the rest (60.4\%) are having qualification of above graduation.

Table 4.3: Educational qualification of the responses

\begin{tabular}{|c|c|c|c|c|c|}
\hline \multicolumn{6}{|c|}{ Qualification } \\
\hline & & Frequency & Percent & Valid Percent & $\begin{array}{c}\text { Cumulative } \\
\text { Percent }\end{array}$ \\
\hline \multirow{4}{*}{ Valid } & Below graduation & 19 & 7.5 & 7.5 & 7.5 \\
\hline & Graduation & 82 & 32.2 & 32.2 & 39.6 \\
\hline & Above graduation & 154 & 60.4 & 60.4 & 100.0 \\
\hline & Total & 255 & 100.0 & 100.0 & \\
\hline
\end{tabular}

From the Table 4.4, it shows that $59.2 \%$ respondents have average income of below 20000, $15.3 \%$ have 20000 and more but less than 30000, $11 \%$ of responses have 30000 and more but less than 40000, 14.5\% have average monthly income of 40000 or more.

4.4: Average monthly income of the respondents

\begin{tabular}{|l|r|r|r|r|}
\hline & Frequency & Percent & Valid Percent & $\begin{array}{c}\text { Cumulative } \\
\text { Percent }\end{array}$ \\
\hline Below 20000 & 151 & 59.2 & 59.2 & 59.2 \\
20000-30000 & 39 & 15.3 & 15.3 & 74.5 \\
Valid $30000-40000$ & 28 & 11.0 & 11.0 & 85.5 \\
40000 and Above & 37 & 14.5 & 14.5 & 100.0 \\
Total & 255 & 100.0 & 100.0 & \\
\hline
\end{tabular}


Reliability Statistics

\begin{tabular}{|r|r|r|}
\hline $\begin{array}{l}\text { Cronbach's } \\
\text { Alpha }\end{array}$ & $\begin{array}{c}\text { Cronbach's } \\
\text { AlphaBased on } \\
\text { Standardized } \\
\text { Items }\end{array}$ & N of Items \\
\hline .884 & .876 & 25 \\
\hline
\end{tabular}

The Cronbach's alpha value is more than.7 i.e..884, so the questionnaire is reliable.

\subsection{Awareness of Consumers about Brand}

Consumer knowledge was calculated on both sides using informative statistics (mean and standard deviation), i.e. customer knowledge and awareness of the brand's chosen highlights.

For a number of results, the mean is the sum of the notes divided by the number of observations. Defines the central position of the data, sometimes referred to as the mean. Standard deviation is the most common indicator of variability, of the distribution of data collection and of the relationship between the mean and the rest of the data. The standard deviation must be high, unless the data points are below the mean and provide fairly consistent responses. Conversely, if many data points are far from the average, the standard deviation must be high. If all values are equal, the default variance is zero.

A. Awareness about selected aspects of brands: This Table 4.5 related with the various aspects of a brand through which respondents are well aware about their favorites global brand (completely unaware to completely aware). The variables which are assessed in this question are Price, Quality, Availability, Variety, Status, Fashionability. The interpretation of these aspects are cited below through frequency distribution.

Table 4.5 Aspects of global brands awareness

\begin{tabular}{|l|l|l|}
\hline Aspects of brand & Frequency & Percentage(\%) \\
\hline Price & 104 & 40.78 \\
Quality & 175 & 68.62 \\
Availability & 70 & 27.45 \\
Variety & 69 & 27.05 \\
Status & 72 & 28.23 \\
Fashionable & 67 & 26.27 \\
\hline
\end{tabular}

In this regard, respondents can be viewed as being highly aware of the quality and price of their favorite global brands as having the highest percentage rating.In respect to other aspect in this chart it is also interpreted that people are less aware about Variety and Fissionability of their favorite's global brand. Status has also an impact on awareness about the brand. From the analysis chart we have seen that quality and price with higher percentage value of 68.62 and 40.78 respectively are being chosen more in respect to other source of brand awareness.

Table 4.6 is related with the various aspects of respondents' favourite local brand and their awareness. The variables which are assessed in this question are Price, Quality, Availability, Variety, Status, Fashionability. The interpretation of these aspects of brand is cited below.

Table 4.6 Aspects of local brands awareness

\begin{tabular}{|l|l|l|}
\hline Aspects of brand & Frequency & Percentage\% \\
\hline Price & 119 & 46.6 \\
Quality & 136 & 53.3 \\
Availability & 99 & 38.8 \\
Variety & 74 & 29.01 \\
Status & 52 & 20.39 \\
Fashionable & 71 & 27.84 \\
\hline
\end{tabular}


In respect to other aspect in this chart it is also interpreted that people are less aware about Fashionability and Status of their favourite local brand. From the analysis chart we have seen that Quality and Price having higher percentage among all the four aspects are being chosen more in respect to other source of brand awareness. Majority of the people thinks that they are more concerned about Quality and Price of their favourite local brand.

B. Sources of Awareness about Brands: There are four sources, through which respondents show their agreement and disagreement on a five point likert scale. After getting the response, it is interpreted that people are more aware about their respective brands from Internet and Advertisement in respect to other sources like Family, Friends and also Shelf Presence. It is because from the chart, the mean value of Internet and Advertisement is higher in respect to other sources, but every source is showing a positive mean value which means somehow every source has a positive impact on the sources of awareness.

From the Table 4.7, researcher has seen that Internet (mean value 3.97) and Advertisement (mean value 3.89) is being chosen more in respect to other source of brand awareness. Majority of the responses lies between agree and strongly agree.

Table 4.7 Sources of awareness

\begin{tabular}{|r|r|r|r|r|}
\hline & People & advertisement & Internet & $\begin{array}{c}\text { Shelf } \\
\text { presence }\end{array}$ \\
\hline N $\quad$ Valid & 255 & 255 & 255 & 255 \\
Missing & 0 & 0 & 0 & 0 \\
Mean & 3.62 & 3.89 & 3.97 & 3.60 \\
Std Deriation & .931 & 1.010 & .998 & 1.021 \\
\hline
\end{tabular}

\subsection{Perception about Brands (Global as well as local)}

Now coming to the second objective of this study, the third question was developed. In this question, the respondents were asked to rate their agreement and disagreement towards their perception about various aspects of global brand and local brand.

Table 4.8: Perception about various aspects of Global Brand

\begin{tabular}{|c|r|r|r|l|r|r|}
\hline & $\begin{array}{c}\text { Reasonable } \\
\text { price }\end{array}$ & Quality & Availability & Variety & Status & Fashionable \\
\hline Nalid & 255 & 255 & 255 & 255 & 255 & 255 \\
Missing & 0 & 0 & 0 & 0 & 0 & 0 \\
Mean & 3.38 & 4.00 & 3.45 & 3.65 & 3.98 & 3.77 \\
Std Deviation & 1.005 & .931 & .970 & .951 & .931 & .872 \\
\hline
\end{tabular}

Quality > Status> Fashionable> Variety > Availability > Price

Quality and status are the same in the eyes of participants with a higher mean value, respectively, of 4.00 and 3.98. Customers know that using the global brand will give them a sign of good standing and it also meets quality expectations. We can also agree that most responses assume that the global brand is more expensive and not available everywhere than local brand.

Table 4.9: Perception about various aspects of Local Brand

\begin{tabular}{|c|r|r|r|r|r|r|}
\hline & $\begin{array}{c}\text { Reasonable } \\
\text { price }\end{array}$ & Quality & Availability & Variety & Status & $\begin{array}{c}\text { Fashionabl } \\
\mathrm{e}\end{array}$ \\
\hline Valid & 255 & 255 & 255 & 255 & 255 & 255 \\
$\mathrm{~N}$ Missing & 0 & 0 & 0 & 0 & 0 & 0 \\
Mean & 3.74 & 3.75 & 3.69 & 3.80 & 3.72 & 3.77 \\
Std.Deviation & .898 & 1.016 & 1.004 & .879 & 1.026 & .946 \\
\hline
\end{tabular}


Variety> Fashionable> Quality> Price> Status> Availability

In local brand it is opposite to the global brand that people perceive Variety and Fashionable more in respect to Status and Quality in global brands with mean value of 3.80 and 3.77 respectively. The other aspects such as Quality, Price, Status and Availability are with lesser mean value respectively. The differentiation in Variety and Quality may be the most important aspect which differentiates the local and global brand from each other. It can also be interpreted that local brands are available at reasonable prices than global brand.

\subsection{Factors affecting the consumer perception about brands}

Reliability is how the evaluation process operates consistently and reliably. Reliability refers to the extent to which repeated interventions result in a scale. Usually measured by the coefficient given by Cronbach. The alpha or alpha coefficient of Cronbach is the sum of all possible partition-half coefficients resulting from different ways of dividing the product. This coefficient ranges from 0 to 1 and typically shows 0.6 or less unsatisfactory reliability within the internal unit (Malhotra, 2008).A strong positive analysis of reliability in all four dimensions can be inferred on the basis of Table 4.10. Overall, the reliability exceeds 0.766.Based on the values set out in Table $4.11 \mathrm{p}(\mathrm{p}>0.05)$, the zero-rate assumptions H01, H02, H03, H04 and H05 are agreed for customer opinions on goods, irrespective of age groups, concerning the equivalent effects of variables (people, local brand preferences, personal experience, prices, advertising, sponsorships and endorsements). Any evidence that rejects the null hypothesis.

Table 4.10 Reliability Statistics

\begin{tabular}{|c|c|}
\hline Cronbach's Alpha & N of Items \\
\hline .766 & 5 \\
\hline
\end{tabular}

There is no significant difference between the different age groups of respondents in the impact of reference groups (families and friends) on their brand perception.

There is no significant difference between the different age groups of respondents about their attraction to local goods and their brand awareness.

There is no significant difference between the different age groups of respondents in the effect of their personal experience on their perception of the product.

The different age groups of respondents do not differ significantly in their public opinions on the impact of identical prices on different goods.

There is no significant difference between the different age groups as to the impact on their brand understanding of advertising / sponsorships / promotions.

Table 4.11 ANOVA

\begin{tabular}{|l|l|r|r|r|r|r|}
\hline & & & & & \\
& & Sum of Squares & Df & Mean Square & F & Sig. \\
\hline \multirow{5}{*}{ People } & & & & & & \\
& Between Groups & 2.390 & 3 & .797 & .701 & .552 \\
& Within Groups & 285.242 & 251 & 1.136 & & \\
& Total & 287.631 & 254 & & & \\
Inclination & Between Groups & .824 & 3 & .275 & .319 & .812 \\
& Within Groups & 216.211 & 251 & .861 & & \\
Experience & Total & 217.035 & 254 & & & \\
& Between Groups & 1.125 & 3 & .375 & .348 & .791 \\
& Within Groups & 270.545 & 251 & 1.078 & & \\
\cline { 2 - 6 } & Total & 271.671 & 254 & & & \\
& Between Groups & 3.314 & 3 & 1.105 & 1.099 & .350 \\
& Within Groups & 252.294 & 251 & 1.005 & & \\
& Total & 255.608 & 254 & & & \\
& Between Groups & 1.761 & 3 & .587 & .582 & .628 \\
& Within Groups & 253.321 & 251 & 1.009 & & \\
& Total & 255.082 & 254 & & & \\
\hline
\end{tabular}


According to Table $4.11 \mathrm{p}$ (p>0.05), the null assumptions H01, H02, H03, H04 and H05 concerning equal impact on the perception of consumer products regardless of age (people, inclination to local brands, personal experience, costs, advertising, sponsorships and endorsements) are recognized. There is no reason to accept the null hypothesis.

There is no significant difference between the different levels of income in the influence of reference groups (family and friends) on their perception of the product.

The different classes of income of respondents do not differ significantly as to whether their preference for local goods affects their brand opinion.

There is no significant difference between the different classes of income as to how their personal experience affects their image of the brand.

There is no significant difference between the different groups of income in the impact of comparative prices on their perception of goods.

The different rates of income of respondents vary considerably in terms of the impact on their brand knowledge of ads / sponsorships / sponsors.

\section{ANOVA}

\begin{tabular}{|c|c|c|c|c|c|c|}
\hline & & Sum of Squares & Df & Mean Square & $\mathbf{F}$ & Sig. \\
\hline \multirow{3}{*}{ People } & Between Groups & 2.650 & 3 & .883 & .778 & .507 \\
\hline & Within Groups & 284.982 & 251 & 1.135 & & \\
\hline & Total & 287.631 & 254 & & & \\
\hline \multirow{3}{*}{ Inclination } & Between Groups & 4.367 & 3 & 1.456 & 1.718 & .164 \\
\hline & Within Groups & 212.668 & 251 & .847 & & \\
\hline & Total & 217.035 & 254 & & & \\
\hline \multirow{3}{*}{ Experience } & Between Groups & .933 & 3 & .311 & .288 & .834 \\
\hline & Within Groups & 270.738 & 251 & 1.079 & & \\
\hline & Total & 271.671 & 254 & & & \\
\hline \multirow{3}{*}{ Price } & Between Groups & 3.295 & 3 & 1.098 & 1.092 & .353 \\
\hline & Within Groups & 252.313 & 251 & 1.005 & & \\
\hline & Total & 255.608 & 254 & & & \\
\hline \multirow{3}{*}{ Advertisement } & Between Groups & 6.141 & 3 & 2.047 & 2.064 & .106 \\
\hline & Within Groups & 248.942 & 251 & .992 & & \\
\hline & Total & 255.082 & 254 & & & \\
\hline
\end{tabular}

\subsection{Key Findings \& Recommendations}

Experts see the Internet as the primary source of brand recognition and advertising. Otherwise, the companies that invest will look at their own strategies. However, we will recognize that most of the responses assume that the global brand is more expensive than the local brand and that it is not available everywhere. Respondents perceive that local brands are available at reasonable price while global brands are costly. The differentiation in Quality and Variety may be the most important aspect which differentiates the global brand and local brand. Status is the second most important aspect in terms of global brand while it is the least important in local brand. There is no impact of any of the factors such as people, price, personal experience, inclination and advertisement on respondents' perception about local and global brands. The demographic factors such as age and income have no impact on these factors about perception.

\subsection{Limitations}

Since we all live in a finite world, there is little we can hope for. We also face a number of obstacles to these studies, which hinder our study. Here are some of the biggest drawbacks. If these limitations are established in the future, the results of studies are expected to be even more detailed. Analysis of global and local brand awareness. Present on the Indian retail market. Estimates of sample size focused only on previous comparable 
studies. If the sample size was measured using some statistical techniques, some valuable information may have been provided.

Constraints on time and money will only affect a small number of respondents. Additional sample cap for convenience. The findings may have been different due to the different types of ready-made clothing (Men's outfit, Women's wear, Kids wear).

\section{References}

1. Aaker, D.A., \& Joachimsthaler, E. (1999). The lure of global branding. Harvard business review, 77, 137-146.

2. Alden, D.L., Steenkamp, J.B.E., \& Batra, R. (1999). Brand positioning through advertising in Asia, North America, and Europe: The role of global consumer culture. Journal of marketing, 63(1), 75-87.

3. Alden, D.L., Kelley, J.B., Riefler, P., Lee, J.A. and Soutar, G.N. (2013), "The effect of global company animosity on global brand attitudes in emerging and developed markets: does perceived value matter?", Journal of International Marketing, Vol. 21 No. 2, pp. 17-38.

4. Alden, D.L., Steenkamp, J.E.M. and Batra, R. (2006), "Consumer attitudes toward marketplace globalization: structure, antecedents and consequences", International Journal of Research in Marketing, Vol. 23 No. 3, pp. 227-39.

5. Apaydin, F., \& Köksal, M.E. (2011). Turkish consumers' risk perception towards global computer brands. International Journal of Marketing Studies, 3(3), 165.

6. Apaydin, F., \& Köksal, M.E. (2011). Turkish consumers' risk perception towards global computer brands. International Journal of Marketing Studies, 3(3), 165.

7. Argenti, P.A., \& Druckenmiller, B. (2004). Reputation and the corporate brand. Corporate reputation review, 6(4), 368-374.

8. Atilgan, E., Akinci, S., Aksoy, S. and Kaynak, E. (2009), "Customer-based brand equity for global brands: a multinational approach”, Journal of Euromarketing, Vol. 18 No. 2, pp. 115-132.

9. Baalbaki, S. and Guzm_an, F. (2016), "A consumer-perceived consumer-based brand equity scale", Journal of Brand Management, Vol. 23 No. 3, pp. 229-251.

10. Balabanis, G., \& Diamantopoulos, A. (2011). Gains and losses from the misperception of brand origin: The role of brand strength and country-of-origin image. Journal of International Marketing, 19(2), 95116.

11. Balabanis, G., \& Diamantopoulos, A. (2011). Gains and losses from the misperception of brand origin: The role of brand strength and country-of-origin image. Journal of International Marketing, 19(2), 95116.

12. Bharadwaj, V.T., Swaroop, G.M. and Vittal, I. (2005), "Winning the Indian consumer", McKinsey Quarterly, Special edition, pp. 42-51.

13. Chatzipanagiotou, K., Veloutsou, C. and Christodoulides, G. (2016), "Decoding the complexity of the consumer-based brand equity process", Journal of Business Research, Vol. 69 No. 11, pp. 5479-5486.

14. Çifci, S., Ekinci, Y., Whyatt, G., Japutra, A., Molinillo, S. and Siala, H. (2016), "A cross validation of consumer-based brand equity models: driving customer equity in retail brands", Journal of Business Research, Vol. 69, No. 9, pp. 3740-3747.

15. Clark, R.A. and Goldsmith, R.E. (2005), "Market mavens: psychological influences", Psychology \& Marketing, Vol. 22 No. 4, pp. 289-312.

16. Cummins, R.A. and Gullone, E. (2000), "Why we should not use 5-point Likert scales: the case for subjective quality of life measurement", Proceedings of the 2nd International Conference on Quality of Life in Cities, National University of Singapore, Singapore, pp. 74-93.

17. Davvetas, V. and Diamantopoulos, A. (2016), "How product category shapes preferences toward global and local brands: a schema theory perspective", Journal of International Marketing, Vol. 24 No. 4, pp. 61-81.

18. Deari, H., \& Balla, E. (2013). Consumers trust in the global brands: Empirical analysis in the context of consumer perspective. European Scientific Journal, 9(1).

19. Dimofte, C. V., Johansson, J. K., \&Ronkainen, I. A. (2008).Cognitive and affective reactions of US consumers to global brands. Journal of International Marketing, 16(4), 113-135.

20. Eelen, J., Ozturan, P. and Verlegh, P.W.J. (2017), "The differential impact of brand loyalty on traditional and online word of mouth: the moderating roles of self-brand connection and the desire to help the brand", International Journal of Research in Marketing, Vol. 34 No. 4, pp. 872-891.

21. Escalas, J.E. and Bettman, J.R. (2005), "Self construal, reference groups, and brand meaning", Journal of Consumer Research, Vol. 32 No. 3, pp. 378-89.

22. Ger, G. (1999). Localizing in the global village: Local firms competing in global markets. California Management Review, 41(4), 64-83. 
23. Gereffi, G., \&Kaplinsky, R. (2001). Introduction: Globalisation, value chains and development. IDS bulletin, 32(3), 1-8.

24. Grixti, J. (2006), "Symbiotic transformations: youth, global media and indigenous culture in Malta", Media, Culture \& Society, Vol. 28 No. 1, pp. 105-22.

25. Hayes, A.F. (2013), Introduction to Mediation, Moderation, and Conditional Process Analysis: A Regression-Based Approach, Guilford Press, New York, NY.

26. Heinberg, M., Ozkaya, E. and Taube, M. (2018), "Do corporate image and reputation drive brand equity in India and China? Similarities and differences", Journal of Business Research, Vol. 86,

27. Hollenbeck, C.R. and Zinkhan, G.M. (2006), "Consumer activism on the internet: the role of anti-brand communities", Advances in Consumer Research, Vol. 33, pp. 479-85.

28. Holt, D. (2004). Managing the interface between suppliers and organizations for environmental responsibility-an exploration of current practices in the UK. Corporate Social Responsibility and Environmental Management, 11(2), 71-84.

29. Ioannou, M. and Rusu, O. (2012), "Consumer-based brand equity: a cross-cultural perspective", Journal of Promotion Management, Vol. 18 No. 3, pp. 344-360.

30. Jenks, M. (2003), "Above and below the line: globalization and urban form in Bangkok", The Annals of Regional Science, Vol. 37 No. 3, pp. 547-57.

31. Johansson, J.K. and Ronkainen, I.A. (2005), "The esteem of global brands", Journal of Brand Management, Vol. 12 No. 5, pp. 339-354.

32. Kang, Y.S. and Herr, P.M. (2006), "Beauty and the beholder: toward an integrative model of communication source effects", Journal of Consumer Research, Vol. 33 No. 1, pp. 123-30.

33. Katsikeas, C.S., Morgan, N.A., Leonidou, L.C. and Hult, G.T.M. (2016), "Assessing performance outcomes in marketing", Journal of Marketing, Vol. 80 No. 2, pp. 1-20.

34. Keller, K. L. (1993). Conceptualizing, measuring, and managing customer-based brand equity. Journal of marketing, 57(1), 1-22.

35. Keller, K. L. (2003). Brand synthesis: The multidimensionality of brand knowledge. Journal of consumer research, 29(4), 595-600.

36. Keller, K.L. (2019), Strategic Brand Management: Building, Measuring, and Managing Brand Equity, Global Edition, Pearson, New York, NY.

37. Khamalah, J. N., \& Lingaraj, B. P. (2003). A study of quality management in small organizations providing services directed at people. Journal of Business \& Economics Research (JBER), 1(2).

38. Kim, C. and Heere, B. (2012), "Consumers from emerging markets: perceptions and attitudes toward global sporting brands", Sport Marketing Quarterly, Vol. 21, pp. 19-31.

39. Kim, H., Damhorst, M. and Lee, K. (2002), "Apparel involvement and advertisement process", Journal of Fashion Marketing and Management, Vol. 6 No. 3, pp. 277-302.

40. Kinra, N. (2006), "The effect of country-of-origin on foreign brand names in the Indian market", Marketing Intelligence \& Planning, Vol. 24 No. 1, pp. 15-30.

41. Krautz, C. (2017), “A cross-cultural study of collective brand perceptions within the brand equity framework, Journal of Marketing Theory and Practice, Vol. 25 No. 3, pp. 274-290.

42. Kumar, A., Lee, H.J. and Kim, Y.K. (2009), "Indian consumers' purchase intention toward a United States versus local brand", Journal of Business Research, Vol. 62, pp. 521-7.

43. Lau, K.C. and Phau, I. (2007), "Extending symbolic brands using their personality: examining antecedents and implications toward brand image fit and brand dilution", Psychology \& Marketing, Vol. 24 No. 5, pp. 421-44.

44. Li, C., Cui, G. and Peng, L. (2017), "The signaling effect of management response in engaging customers: a study of the hotel industry", Tourism Management, Vol. 62, pp. 42-53.

45. Lieven, T. and Hildebrand, C. (2016), "The impact of brand gender on brand equity", International Marketing Review, Vol. 33 No. 2, pp. 178-195.

46. Maaninou, N., Huaman-Ramirez, R. and Cova, V. (2019), "Brand oldness associations: identification of dimensions and measurement", Paper presented at the Academy of Marketing Science Annual Conference, May, Vancouver, Canada.

47. Maclaran, P. and Brown, S. (2005), "The center cannot hold: consuming the utopian marketplace", Journal of Consumer Research, Vol. 32 No. 2, pp. 311-23.

48. Oh, H. and Kim, K. (2017), "Customer satisfaction, service quality, and customer value: years 20002015”, International Journal of Contemporary Hospitality Management, Vol. 29 No. 1, pp. 2-29.

49. Ortiz, M.H., Reynolds, K.E. and Franke, G.R. (2013), "Measuring consumer devotion: antecedents and consequences of passionate consumer behavior", Journal of Marketing Theory and Practice, Vol. 21 No. 1, pp. 7-29.

50. Ozsomer, A. (2012), "The interplay between global and local brands: a closer look at perceived brand globalness and local iconness”, Journal of International Marketing, Vol. 20 No. 2, pp. 72-95. 
51. Park, C.W., MacInnis, D. and Eisingerich, A. (2016), Brand Admiration: Building a Business People Love, John Wiley \& Sons, Honoken, NJ.

52. Piacentini, M. and Mailer, G. (2004), "Symbolic consumption of teenagers' clothing choices", Journal of Consumer Behavior, Vol. 3 No. 3, pp. 251-62.

53. Pichler, E.A. and Hemetsberger, A. (2008), "Driven by devotion: how consumers interact with their objects of devotion", in Lee, A.Y. and Soman, D. (Eds.), NA - Advances in Consumer Research, Vol. 35, Association for Consumer Research, Duluth, MN, pp. 439-444.

54. Pitta, D. and Franzak, F. (2008), "Foundations for building share of heart in global brands", Journal of Product \& Brand Management, Vol. 17No. 2, pp. 64-72.

55. Rajasekar, N. and Nalina, K.G. (2008), "Measuring customer-based brand equity in durable goods industry", Journal of Marketing and Communication, Vol. 4 No. 1, pp. 48-58.

56. Randrianasolo, A.A. (2017), "Global brand value in developed, emerging, and least developed country markets", Journal of Brand Management, Vol. 24 No. 5, pp. 489-507.

57. Romaniuk, J., Dawes, J. and Nenycz-Thiel, M. (2018), "Modeling brand market share change in emerging markets", International Marketing Review, Vol. 35 No. 5, pp. 785-805.

58. Samiee, S. (2019), "Reflections on global brands, global consumer culture and globalization", International Marketing Review, Vol. 36, No. 4, pp. 536-544.

59. Sandikci, O. and Omeraki, S. (2007), "Islam in the marketplace: does Ramadan turn into Christmas?", Advances in Consumer Research, Vol. 34.

60. Schniederjans, M. J., Parast, M. M., Nabavi, M., Rao, S. S., \& Raghu-Nathan, T. S. (2006). Comparative analysis of Malcolm Baldrige national quality award criteria: an empirical study of India, Mexico, and the United States. Quality Management Journal, 13(4), 7-21.

61. Schuiling, I., \&Kapferer, J. N. (2004). Executive insights: real differences between local and international brands: strategic implications for international marketers. Journal of international marketing, 12(4), 97-112.

62. Speck, S.K.S. and Roy, A. (2008), "The interrelationships between television viewing, values and perceived well-being: a global perspective", Journal of International Business Studies, Vol. 39, pp. 1197-219.

63. Staudt, S., Shao, C.Y., Dubinsky, A.J. and Wilson, P.H. (2014), "Corporate social responsibility, perceived customer value, and customer-based brand equity: a cross-national comparison", Journal of Strategic Innovation and Sustainability, Vol. 10 No. 1, pp. 65-87.

64. Torres, A., Bijmolt, T.H.A., Trib_o, J.A. and Verhoef, P. (2012), "Generating global brand equity through corporate social responsibility to key stakeholders", International Journal of Research in Marketing, Vol. 29 No. 1, pp. 13-24.

65. Townsend, J.D., Yeniyurt, S. and Talay, M.B. (2009), "Getting to global: an evolutionary perspective of brand expansion in international markets”, Journal of International Business Studies, Vol. 40 No. 4, pp. 539-58.

66. Van der Westhuizen, L.. (2018), "Brand loyalty: exploring self-brand connection and brand experience", Journal of Product \& Brand Management, Vol. 27 No. 2, pp. 172-184.

67. Veloutsou, C., Christodoulides, G. and de Chernatony, L. (2013), "A taxonomy of measures for consumer-based brand equity: drawing on the views of managers in Europe", Journal of Product \& Brand Management, Vol. 22 No. 13, pp. 238-248.

68. Vukasovi_c, T. (2016), "An empirical investigation of brand equity: a cross-country validation analysis", Journal of Global Marketing, Vol. 29 No. 5, pp. 251-264.

69. Wadhwa, M. and Zhang, K. (2015), "This number just feels right: the impact of roundedness of price numbers on product evaluations", Journal of Consumer Research, Vol. 41 No. 5, pp. 1172-1185.

70. Winit, W., Gregory, G., Cleveland, M. and Verlegh, P. (2014), "Global vs local brands: how home country bias and price differences impact brand evaluations", International Marketing Review, Vol. 31 No. 2, pp. 102-128.

71. Zarantonello, L. and Pauwels-Delassus, V. (2015), The Handbook of Brand Management Scales, Routledge, London.

72. Zarantonello, L., Formisano, M. and Grappi, S. (2016), "The relationship between brand love and actual brand performance: evidence from an international study", International Marketing Review, Vol. 33 No. 6, pp. 806-824.

73. Zarantonello, L., Jedidi, K. and Schmitt, B.H. (2013), "Functional and experiential routes to persuasion: an analysis of advertising in emerging vs. developed markets", International Journal of Research in Marketing, Vol. 30 No. 1, pp. 46-56.

74. Zhang, S., van Doorn, J. and Leeflang, P. (2014), "Does the importance of value, brand and relationship equity for customer loyalty differ between eastern and western cultures?", International Business Review, Vol. 23, No. 1, pp. 284-292. 
75. Zhang, Y. and Khare, A. (2009), "The impact of accessible identities on the evaluation of global versus local products", Journal of Consumer Research, Vol. 36, pp. 524-37. 